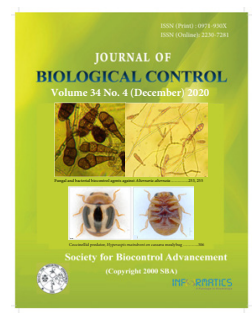

\title{
Behaviour of Orius insidiosus Say (Hemiptera: Anthocoridae) towards its prey, Thrips palmi Karny (Thysanoptera: Thripidae)
}

\author{
KENNEDY PAUL* and AYUB KHAN \\ Department of Life Sciences, University of the West Indies, St. Augustine, Trinidad and Tobago \\ *Corresponding authorE-mail: kennedy.a.paul@gmail.com,ayub.khan@sta.uwi.edu
}

\begin{abstract}
The behaviour of $5^{\text {th }}$ instar nymphs and adult males and females of anthocorid bug, Orius insidiosus preying on adult Thrips palmi was studied. Adult $O$. insidiosus males spent longest time in motion compared with $5^{\text {th }}$ instar nymphs and adult females. First encounter of prey was shortest for $5^{\text {th }}$ instar nymphs but not significantly different from that of adult females. The distance travelled to $1^{\text {st }}$ prey by $5^{\text {th }}$ instar nymphs was significantly shortest compared to both adult male and female $O$. insidiosus. However, speed of arrival to $1^{\text {st }}$ prey did not significantly differ among the three stages of $O$. insidiosus examined. Mean time spent by $O$. insidiosus $5^{\text {th }}$ instar nymphs and adult females on $1^{\text {st }}, 2^{\text {nd }}, 3^{\text {rd }}$ and $4^{\text {th }}$ prey encounters was not significantly different. However, adult males of $O$. insidiosus spent significantly less time on $4^{\text {th }}$ prey encounter compared with $1^{\text {st }}-3^{\text {rd }}$ prey encounters.
\end{abstract}

KEY WORDS: Feeding behaviour, Orius insidiosus, searching efficiency, Thrips palmi

(Article chronicle: Received: 12-11-2018; Revised: 20-11-2020; Accepted: 25-11-2020)

\section{INTRODUCTION}

Orius insidiosus Say (Hemiptera: Anthocoridae) has been identified as an important biological control agent for thrips and other soft-bodied insects because of its ability to successfully prey on different species of thrips at various instars in complex environments (Baez et al., 2004). An insect's searching behaviour is an active movement by which it seeks resources such as food, mates, oviposition and nesting sites and refugia. For this reason, it is imperative that insects have efficient searching mechanisms, since the above mentioned resources are essential for growth, development, maintenance of the individual and for ensuring survival and reproduction (Bell, 1990).

Augmentative biological control of pests with arthropod natural enemies has become increasingly popular worldwide and is now an important facet of Integrated Pest Management systems in open fields and greenhouses (Yano et al., 2005). There is a number of Orius spp., which is known natural enemies of soft bodied arthropods globally. In Trinidad and Tobago, $O$. insidiosus is a natural enemy of T. palmi on melongene (Solanum melongena). Orius spp. such as
Orius sauteri Poppius (Heteroptera: Anthocoridae) has proven effective in management of T. palmi on S. melongena (Kawai, 1995) and has been a registered biological control agent for commercial use in greenhouses since 1998 (Yano et al., 2005). Sabelis and van Rijn (1997) developed models to describe patch exploitation behaviour and discussed the implications of predation rate and biological control of spider mites with Phytoseiulus persimilis (Athias-Henriot) (Acarina:Phytoseiidae). If $O$. insidiosus is to be considered a potential biological control agent for T. palmi in S. melongena in Trinidad and Tobago, a control program must be established. Evaluation of foraging potential of natural enemies is the most critical phase in development of biological control programmes (van Lenteren and Manzaroli, 1999). Searching efficiency is an important parameter which must be assessed in every potential biological control agent (Yano et al., 2005) as this parameter gives an indication of the predator's ability to find resources in a manner which is sustainable, thus ensuring the survival of its future generations. The present study investigates the searching efficiency and foraging and feeding behaviour of $O$. insidiosus on T. palmi. 


\section{MATERIALS AND METHODS}

\section{Rearing of $\boldsymbol{O}$. insidiosus}

The predator, Orius insidiosus and its preferred prey $T$. palmi were taken from a laboratory culture maintained at 27 $\pm 2^{\circ} \mathrm{C}$ and $70 \pm 5 \%$ relative humidity. Ten each of $1-2$ day old adult males, adult females and 1-day old $5^{\text {th }}$ instar nymphs were selected for the experiments. The predators were fed with T. palmi and placed individually in $2 \mathrm{ml}$ Eppendorf ${ }^{\mathbb{B}}$ centrifuge tubes, loosely covered with a moist piece of cotton, where they were starved for $6 \mathrm{~h}$ prior to conduct of the experiments.

\section{Predation monitoring}

Four immobilized adult T. palmi were placed at the centre of a $9 \mathrm{~cm}$ diameter petri-dish lined with moistened filter paper at the base. Either 1 adult male, adult female or $5^{\text {th }}$ instar $O$. insidiosus was introduced into the petri-dish the top of which was covered with a glass plate. The behaviour of $O$. insidiosus was observed and recorded, while movement of $O$. insidiosus in the petri-dish was traced on the glass plate using a Sharpie ${ }^{\circledR}$ fine point marker until the prey was found. The experiment was replicated ten times for each of the three predator stages indicated. The following measurements on $O$. insidiosus were taken during the conduct of the experiment: time spent in motion, time spent stationary, arrival time to first prey, departure time from first, distance travelled to $1^{\text {st }}$ prey, speed of arrival to $1^{\text {st }}$ prey, time to different prey encounters and number of pricks per prey encounter (PPE) by all three stages of $O$. insidiosus.

\section{Statistical analysis}

Data collected were normalized using square root transformation and then subjected to Analysis of Variance (ANOVA) followed by Tukey-Kramer post hoc test (Gomez and Gomez, 1984).

\section{RESULTS}

Adult male $O$. insidiosus spent significantly more time $(1953.11 \pm 483.67 \mathrm{~s})$ in motion compared to $5^{\text {th }}$ instar nymphs $(645 \pm 119.05 \mathrm{~s})\left(\mathrm{F}_{2,23}=4.749, \mathrm{p}=0.0188\right)$. However, there was no significant difference $(\mathrm{P}>0.05)$ between the time spent in motion for either $5^{\text {th }}$ instar nymphs and females or males and females (Table 1). Fifth instar nymphs of $O$. insidiosus spent significantly less time stationary $(1148.38 \pm 288.37 \mathrm{~s})$ compared to males $\left(\mathrm{F}_{2,23}=4.448, \mathrm{p}=0.0233\right)$. There was no significant difference $(\mathrm{P}>0.05)$ in the time spent stationary between either $5^{\text {th }}$ instar nymphs and females or males and females (Table 1).

Time of arrival to $1^{\text {st }}$ prey by the three stages of $O$. insidiosus examined varied considerably. Fifth instar nymphs took significantly shorter mean time $(1791.63 \pm 321.97 \mathrm{~s})$ to arrive at $1^{\text {st }}$ prey compared to adult male O. insidiosus $\left(\mathrm{F}_{2}\right.$, $\left.{ }_{23}=5.414, \mathrm{p}=0.0118\right)$. Females also arrived at $1^{\text {st }}$ prey significantly $(\mathrm{P}<0.05)$ faster $(2166.78 \pm 410.29 \mathrm{~s})$ compared to males, however, there was no significant difference $(\mathrm{P}>0.05)$ between the time to $1^{\text {st }}$ prey arrival by either $5^{\text {th }}$ instar nymphs or females (Table 1).

Numerically, males appeared to spend more time on $1^{\text {st }}$ prey $(6331.11 \pm 1688.20 \mathrm{~s})$ compared to $5^{\text {th }}$ instar nymphs $(3179.50 \pm 224.00 \mathrm{~s})$ and females $(3370.56 \pm 509.96 \mathrm{~s})$ however, the mean time of departure from $1^{\text {st }}$ prey by all three stages of $O$. insidiosus tested did not vary significantly from each other $\left(\mathrm{F}_{2,23}=2.785, \mathrm{p}=0.0826\right)$ (Table 1$)$.

The mean distance travelled by $O$. insidiosus $5^{\text {th }}$ instar nymphs, males and females before arriving at $1^{\text {st }}$ prey given in Table 1 indicates that fifth instar nymphs travelled a significantly shorter mean distance $(77.84 \pm 12.99 \mathrm{~cm})$ before arriving at their $1^{\text {st }}$ prey compared to either male $(254.86 \pm$ $42.03 \mathrm{~cm})$ or female $(275.51 \pm 54.23 \mathrm{~cm})\left(\mathrm{F}_{2,23}=6.480, \mathrm{p}\right.$ $=0.0059)$ O insidiosus. There was no significant difference $(\mathrm{P}>0.05)$ between the mean distance travelled by either males or females before arrival at $1^{\text {st }}$ prey. Likewise, mean walking speed to arrival of all three stages of $O$. insidiosus to $1^{\text {st }}$ prey was not significantly different from each other $\left(\mathrm{F}_{2,23}=1.774\right.$, $\mathrm{p}=0.1921)$ (Table 1).

The mean time taken by $5^{\text {th }}$ instar, male and female $O$. insidiosus to encounter their $1^{\text {st }}$ prey differed significantly between them $\left(\mathrm{F}_{2,23}=3.662, \mathrm{p}=0.0416\right)$ with males taking the longest time $(853.00 \pm 22.27 \mathrm{~s})$ compared to either $5^{\text {th }}$ instar nymphs $(377.00 \pm 70.76 \mathrm{~s})$ or females $(362.22 \pm 81.34$ s) (Table 2). Mean time to $2^{\text {nd }}$ prey encounter by all three stages of $O$. insidiosus was not significantly different from each other $\left(\mathrm{F}_{2,18}=0.3733, \mathrm{p}=0.6937\right)$. Fifth instar nymphs took an average of $270.00 \pm 83.06 \mathrm{~s}$ to encounter their $2^{\text {nd }}$ prey while females and males took an average of $307.86 \pm$ $91.33 \mathrm{~s}$ and $370.43 \pm 42.67 \mathrm{~s}$ respectively (Table 2). Females encountered their $3^{\text {rd }}$ prey in significantly less time compared to males $\left(\mathrm{F}_{2,13}=5.077, \mathrm{p}=0.0235\right)$ however there was no difference in time to encounter $3^{\text {rd }}$ prey by either $5^{\text {th }}$ instar nymphs and males or $5^{\text {th }}$ instar nymphs and females (Table 2 ). There was no significant difference in time to $4^{\text {th }}$ prey encounter by either $5^{\text {th }}$ instar nymphs, males or females of $O$. insidiosus $\left(\mathrm{F}_{2,12}=1.338, \mathrm{p}=0.2988\right)$. The times to $1^{\mathrm{st}}, 2^{\text {nd }}$, $3^{\text {rd }}$ and $4^{\text {th }}$ prey encounters were not significantly different $(\mathrm{P}>0.05)$ for that of $5^{\text {th }}$ instar and female $O$. insidiosus. However, male $O$. insidiosus spent significantly more time for their $1^{\text {st }}$ prey encounter compared with that of $2^{\text {nd }}, 3^{\text {rd }}$ or $4^{\text {th }}$ prey encounter $\left(\mathrm{F}_{3,36}=129.05, \mathrm{p}<0.0001\right)$. Significantly least time was spent for their $4^{\text {th }}$ prey encounter (Table 2). The number of pricks by $O$. insidiosus $5^{\text {th }}$ instar nymphs, males and females did not vary significantly for $1^{\text {st }}\left(\mathrm{F}_{2,23}=1.129, \mathrm{p}\right.$ $=0.3406), 2^{\text {nd }}\left(\mathrm{F}_{2,22}=1.669, \mathrm{p}=0.2114\right), 3^{\text {rd }}\left(\mathrm{F}_{2,18}=1.718\right.$, $\mathrm{p}=0.2076)$ or $4^{\text {th }}\left(\mathrm{F}_{2,13}=1.713, \mathrm{p}=0.2185\right)$ prey encounter (Table 3). 
Behaviour of anthocorid bug,, Orius insidiosus towards its prey, Thrips palmi

Table 1: Searching behaviour parameters of three stages of Orius insidiosus to Thrips palmi

\begin{tabular}{|l|c|c|c|}
\hline \multirow{2}{*}{ Parameter } & \multicolumn{3}{|c|}{ Orius insidiosus (Mean \pm S.E.) } \\
\cline { 2 - 4 } & $\mathbf{5}^{\text {th }}$ instar $\mathbf{n y m p h}$ & Male & \multicolumn{2}{c|}{ Female } \\
\hline Time in motion (s) & $645.00 \pm 119.05^{\mathrm{a}}$ & $1953.11 \pm 483.67^{\mathrm{bc}}$ & $901.22 \pm 109.92^{\mathrm{ac}}$ \\
\hline Time spent stationary (s) & $1144.38 \pm 288.37^{\mathrm{a}}$ & $3686.33 \pm 159.60^{\mathrm{bc}}$ & $1357.56 \pm 257.28^{\mathrm{ac}}$ \\
\hline First prey arrival time (s) & $1791.63 \pm 321.97^{\mathrm{a}}$ & $5639.44 \pm 144.24^{\mathrm{b}}$ & $2166.78 \pm 410.29^{\mathrm{a}}$ \\
\hline First prey departure time (s) & $3179.50 \pm 224.00^{\mathrm{a}}$ & $6331.11 \pm 1688.20^{\mathrm{a}}$ & $3370.56 \pm 509.96^{\mathrm{a}}$ \\
\hline Distance travelled to $1^{\text {st }}$ prey $(\mathrm{cm})$ & $77.84 \pm 12.99^{\mathrm{a}}$ & $254.86 \pm 42.03^{\mathrm{b}}$ & $275.51 \pm 54.23^{\mathrm{b}}$ \\
\hline Speed of arrival to $1^{\text {st }}$ prey $(\mathrm{cm} / \mathrm{s})$ & $0.19 \pm 0.05^{\mathrm{a}}$ & $0.19 \pm 0.03^{\mathrm{a}}$ & $0.29 \pm 0.05^{\mathrm{a}}$ \\
\hline
\end{tabular}

* Values followed by the same letter along a row are not significantly different $(\mathrm{P}>0.05)$ from each other based on Tukey-Kramer Multiple Comparisons Test.

Table 2: Mean time spent by Orius insidiosus on different prey encounters

\begin{tabular}{|c|c|c|c|c|}
\hline \multirow[t]{2}{*}{ Stage } & \multicolumn{4}{|c|}{ Mean duration (s) \pm S.E. spent on different prey encounters* } \\
\hline & $1^{\text {st }}$ prey encounter & $2^{\text {nd }}$ prey encounter & $3^{\text {rd }}$ prey encounter & $4^{\text {th }}$ prey encounter \\
\hline $5^{\text {th }}$ instar & $377.00 \pm 70.76^{\mathrm{aA}}$ & $270.00 \pm 83.06^{\mathrm{aA}}$ & $320.00 \pm 71.03^{\mathrm{aA}}$ & $310.00 \pm 80.07^{\mathrm{aA}}$ \\
\hline Male & $853.00 \pm 22.27^{\mathrm{bA}}$ & $370.43 \pm 42.67^{\mathrm{aB}}$ & $560.20 \pm 21.98^{\mathrm{abC}}$ & $111.63 \pm 15.12^{\mathrm{aD}}$ \\
\hline Female & $362.22 \pm 81.34^{\mathrm{cA}}$ & $307.86 \pm 91.33^{\mathrm{aA}}$ & $172.50 \pm 38.34^{\mathrm{acA}}$ & $295.20 \pm 15.37^{\mathrm{aA}}$ \\
\hline
\end{tabular}

*Values followed by the same lowercase letter along a column and the same uppercase letter along a row are not significantly different (P>0.05) from each other based on Tukey-Kramer Multiple Comparisons Test.

Table 3: Mean pricks per prey encounter by three stages of Orius insidiosus

\begin{tabular}{|c|c|c|c|c|}
\hline \multirow[t]{2}{*}{ Stage } & \multicolumn{4}{|c|}{ Mean pricks per prey encounter \pm S.E.* } \\
\hline & $\begin{array}{c}\text { Pricks / } 1^{\text {st }} \\
\text { prey encounter }\end{array}$ & Pricks $/ 2^{\text {nd }}$ prey encounter & $\begin{array}{c}\text { Pricks / } 3^{\text {rd }} \\
\text { prey encounter }\end{array}$ & $\begin{array}{c}\text { Pricks / } 4^{\text {th }} \\
\text { prey encounter }\end{array}$ \\
\hline $5^{\text {th }}$ instar & $3.13 \pm 0.40^{\mathrm{aA}}$ & $2.00 \pm 0.53^{\mathrm{aA}}$ & $1.83 \pm 0.48^{\mathrm{aA}}$ & $2.17 \pm 0.48^{\mathrm{aA}}$ \\
\hline Male & $4.56 \pm 0.69^{\mathrm{aA}}$ & $3.44 \pm 0.58^{\mathrm{aA}}$ & $3.14 \pm 0.67^{\mathrm{aA}}$ & $4.40 \pm 1.21^{\mathrm{aA}}$ \\
\hline Female & $4.00 \pm 0.80^{\mathrm{aA}}$ & $2.25 \pm 0.70^{\mathrm{aA}}$ & $2.25 \pm 0.31^{\mathrm{aA}}$ & $3.00 \pm 0.89^{\mathrm{aA}}$ \\
\hline
\end{tabular}

*Values followed by the same lowercase letter along a column or uppercase letter along a row are not significantly different $(\mathrm{P}>0.05)$ from each other based on Tukey-Kramer Multiple Comparisons Test.

\section{DISCUSSION}

Searching activities including probing and walking were observed for $O$. insidiosus male, female and $5^{\text {th }}$ instar nymphs. Visual observations of $O$. insidiosus predation on T. palmi indicated that the sequence followed was: arousal-approach, capturing-probing-piercing and then sucking which was similar to that exhibited by Sphedanolestes variabilis Distant (Hemiptera: Reduviidae) (Ambrose et al., 2009). It was observed that as $O$. insidiosus adults and $5^{\text {th }}$ instar nymphs searched for T. palmi their proboscises were stretched forward while continuously probing with their antennae which were extended anteriorly. Cocuzza et al. (1997) reported a similar behaviour in both Orius laevigatus (Fieber) and Orius albidipennis (Reuter) when preying on Frankiniella occidentalis (Pergande) (Thysanoptera: Thripidae).

Orius spp. are known to only partially exploit prey patches since they can only identify prey items by touch using predominantly their legs and antennae during searching (Yano et al., 2005) and to short range chemical cues on prey infested leaves (Castane et al., 1999; Lattin, 1999; Yano et al., 2005). Stationary prey items (T. palmi) were used in the current study since it may have been very difficult for $O$. insidiosus to locate mobile prey in the absence of chemical cues. Mendes and Bueno (2001) and Bueno (2009) reported that $O$. insidiosus surveys an entire leaf in search of its prey by moving its head from side-to-side; when it detects a prey, its antennae move in the prey's direction and it walks toward the prey with its rostrum extended. Moreover, Loureiro and Júnior (2007) noted that $O$. insidiosus cleans its stylet and antennae after predation of the aphid A. gossypii. As biocontrol agents, Orius spp. are generalist predators which are released at high prey densities and are expected to perform efficiently even when satiated (Yano et al., 2005). However, Shields (1979) observed that starved Orius tristicolor (White) covered $20 \%$ more distance that unstarved individuals. In the 
current study, $O$. insidiosus travelled longer distances to the prey patch than males or $5^{\text {th }}$ instar nymphs. Shields (1979) also found that female O. tristicolor covered $29 \%$ more distance than males. A similar trend was found in the present study with $O$. insidiosus females covering $21 \%$ more distance to $1^{\text {st }}$ prey than males.

Although there was no significant difference between mean speeds of arrival by $O$. insidiosus males, females and $5^{\text {th }}$ instar nymphs to $1^{\text {st }}$ prey, females had numerically the highest mean speed whilst searching for the prey patch. Yano et al. (2005) also concluded that the walking speed of $O$. sauteri increased as they approached the prey patch. Females of $O$. insidiosus spent less time on the $1^{\text {st }}$ prey encounter than $5^{\text {th }}$ instar nymphs and males. Adult females generally spent little time on all prey encounters (prey patch) and this may be advantageous because prey patches with little or no chance to encounter prey will be vacated faster in search of food by $O$. insidiosus when no prey has been encountered for some time.

Orius insidiosus fed by inserting its proboscis into the abdomen of T. palmi. Most stung and manoeuvred their prey into submission before quickly switching to other prey in the patch. On several occasions $O$. insidiosus females, males and $5^{\text {th }}$ instar nymphs were observed puncturing (with proboscis) or stinging (with ovipositor in the case of females) usually the abdomen of T. palmi without actual consumption. This resulted in death of $T$. palmi, which can be regarded as beneficial in the case of a predator used for biological control and is a common behaviour by insect predators when they encounter a prey patch (Rajasekhara and Chatterji, 1970). A similar sequence of events was recorded by Yano et al. (2005) for O. sauteri including the fact that it only partially exploited each prey patch. Biocontrol agents such as Orius spp. are generally introduced into a field or greenhouse when pests are at high population densities. Predators can be satiated shortly after being introduced to a prey patch but are expected to continue to control pest populations. Yano et al. (2005) suggested that Orius spp. attack tendencies were not regulated by their level of starvation. At lower prey densities, the search efficiency is lower (O'Neil, 1988) due to the energy cost of locating prey. At higher densities, De Clercq and Degheele (1994) reported that the predation rate may be increased due to the ease with which predators encounter prey, causing the predator to abandon its prey before it is fully consumed.

\section{REFERENCES}

Ambrose DP, Rajan SJ, Nagarajan K, Krishnan SS. 2009. Biology, behaviour and functional response of Sphedanolestes variabilis Distant (Hemiptera: Reduviidae), a potential predator of lepidopteran pests. Entomol Croatia. 13: 33-44.
Baez I, Reitz S, Funderburk JE. 2004. Predation by Orius insidiosus (Heteroptera: Anthocoridae) on life stages and species of Frankliniella on flower thrips (Thysanoptera:Thripidae) in pepper flowers. Environ Entomol. 33: 662-670. https://doi.org/10.1603/0046225X-33.3.662

Bell WJ. 1990. Searching behaviour patterns in insects. Annu Rev Entomol. 35: 447-467. https://doi.org/10.1146/annurev.en.35.010190.002311

Bueno VHP. 2009. Desenvolvimento e criacao massal de percevejos predadores Orius. In: Bueno VHP (Ed.) Controle biologico de pragas: producao massal e controle de qualidade, Lavras, Brasil: UFLA Publications, pp. 33-76.

Castañé C, Riudavets J, Yano E. 1999. Biological control of thrips. In: Albajes R, Gullino MA, van Lenteren JC and Elad Y (Eds.) Integrated Pest and Disease Management in Greenhouse Crops, Dordrecht, the Netherlands: Kluwer Academic Publishers, pp. 244-253. https://doi. org/10.1007/0-306-47585-5_17

Cocuzza GE, De Clerq P, Lizzo S, Van De Veire M, Tirry L, Degheele D, Vacante V. 1997. Life tables and predation activity of Orius laevigatus and O. albidipennis at three constant temperatures. Entomol Exp Applic. 85: 189198. https://doi.org/10.1046/j.1570-7458.1997.00249.x

De Clerq P, Degheele D. 1994. Laboratory measurement of predation by Podisus maculiventris and P. sagitta (Hemiptera: Pentatomidae) on beet armyworm (Lepidoptera: Noctuidae). J Econ Entomol. 87: 76-83. https://doi.org/10.1093/jee/87.1.76

Gomez KA, Gomez AA. 1984. Statistical Procedures in Agricultural Research, New Jersey: Wiley-Interscience, $704 \mathrm{p}$.

Kawai A. 1995. Control of Thrips palmi Karny (Thysanoptera: Thripidae) by Orius spp. (Heteroptera: Anthocoridae) on greenhouse eggplant. Appl Entomol Zool. 30: 1-7. https://doi.org/10.1303/aez.30.1

Lattin JD. 1999. Bionomics of the Anthocoridae. Annu Rev Entomol. 44: 207-231. https://doi.org/10.1146/annurev. ento.44.1.207 PMid:15012372

Loureiro ES, Júnior AM. 2007. Patogenicidade de fungos entomopatogênicos a Orius insidiosus (Say) (Hemiptera: Anthocoridae). BioAssay. 2: 1-8. https://doi.org/10.14295/BA.v2.0.15 
Behaviour of anthocorid bug,, Orius insidiosus towards its prey, Thrips palmi

Mendes SM, Bueno VHP. 2001. Biologia de Orius insidiosus (Say) (Hemiptera: Anthocoridae) alimentado com Caliothrips phaseoli (Hood) (Thysanoptera: Thripidae). Neotrop Entomol. 30: 423-428 https://doi.org/10.1590/ S1519-566X2001000300014

O’Neil RJ. 1988. Predation by Podisus maculiventris Say on Mexican bean beetle Epilachna varvestris Mulsant in Indian soyabeans. Can Entomol. 120: 161-166. https:// doi.org/10.4039/Ent120161-2

Rajasekhara K, Chatterji S. 1970. Biology of Orius indicus (Hemiptera: Anthocoridae), a predator of Taeniothrips nigricornis (Thysanoptera). Ann Entomol Soc Amer. 63: 364-367. https://doi.org/10.1093/aesa/63.2.364

Sabelis MW, van Rijn PCJ. 1997. Predation by insects and mites. In: Lewis T (Ed.) Thrips as Crop Pests, New York, NY, USA: Oxford University Press/CAB International, pp. 259-354.
Shields EJ. 1979. Searching behaviour of Orius tristicolor (White) on cotton. Master of Science thesis University of Arizona, USA. 72pp.

van Lenteren JC, Manzaroli G. 1999. Evaluation and use of predators and parasitoids for biological control of pests in greenhouses. In: Albajes R, Gullino ML, van Lenteren JC and Elad Y (Eds.). Integrated Pest and Disease Management in Greenhouse Crops, Dordrecht, the Netherlands: Kluwer Academic Publishers, pp. 183201. https://doi.org/10.1007/0-306-47585-5_13

Yano E, Jiang N, Hemerik L, Mochizuki M, Mitsunaga T, Shimoda T. 2005. Time allocation of Orius sauteri in attacking Thrips palmi on an eggplant leaf. Entomol Exp Applic. 117: 177-184. https://doi.org/10.1111/j.15707458.2005.00347.x 